\title{
The Interaction of Homozygote 192-bp I nsulin-like growth factor-1 ( IGF-1) Polymorphisms and C igarette Smoking to End -stage renal disease ( ESRD)
}

\section{Titiek Hidayati}

Universitas Muhammadiyah Yogyakarta

Akrom Akrom ( $\square$ akmaa_uad@yahoo.co.id )

Universitas Ahmad Dahlan https://orcid.org/0000-0002-1792-722X

Chih Chih Chang

National Cheng Kung University College of Medicine

\section{Research note}

Keywords: 192bp allele IGF-1 gene, 188bp allele IGF-1 gene, IGF-1 CA repeat polymorphism, genesmoking interaction, ESRD, case-control

Posted Date: January 15th, 2021

DOI: https://doi.org/10.21203/rs.3.rs-145980/v1

License: (c) (i) This work is licensed under a Creative Commons Attribution 4.0 International License.

Read Full License 


\section{Abstract}

Objective: Smoking and end-stage renal disease (ESRD) are the leading public health problems in Indonesia. Smoking is a known risk factor for the development and progression of ESRD. Specific genetic polymorphisms may modify the harmful effects of cigarette smoking and may also change the inherited risk. IGF-1 CA repeat polymorphism is thought to be associated with an increased incidence of chronic kidney disease in smokers. We investigated the impact of smoking interactions with IGF-1 CA repeat polymorphism with the rate of chronic kidney disease in Yogyakarta Special Region Indonesia. (YSRI)

Result: Our study found that smoking and IGF-1 genotype 192 bp are risk factors for ESRD in Indonesia. The combination of genotype $192 \mathrm{bp}$ and smoking is associated with increased ESRD events.

Respondents with smoking habits and 192 bp homozygous genotype are at high risk of ESRD. Smoking habit and homozygous 192 bp genotype are strongly interaction.. There was a mild interaction between respondents with smoking habits and heterozygous $192 \mathrm{bp}$ and $188 \mathrm{bp}$. There was no interaction between non-smokers with heterozygous 192 bp and 188 bp of the IGF-1 gene.

\section{Full Text}

This preprint is available for download as a PDF.

\section{Supplementary Files}

This is a list of supplementary files associated with this preprint. Click to download.

- supplemendatarevisedrsns20025191.pdf 